\title{
VARIABLE VENTILATION COMPARED WITH RECRUITMENT MANOEUVRES IN A PORCINE MODEL OF ARDS
}

Duane J. Funk MD ${ }^{1}$, M. Ruth Graham MD ${ }^{1}$, Linda G. Girling BSc ${ }^{1}$, James A. Thliveris $\mathrm{PhD}^{2}$, Bruce M. McManus MD PhD ${ }^{5}$, Elizabeth K-Y. Walker MSc${ }^{5}$, Edward S. Rector $\mathrm{PhD}^{3}$, Craig Hillier BSc${ }^{4}$, J. Elliott Scott $\mathrm{PhD}^{4}$ and W. Alan C. Mutch $\mathrm{MD}^{1}$

From the Departments of Anesthesia ${ }^{1}$, Human Anatomy and Cell Science ${ }^{2}$, Immunology ${ }^{3}$ and Oral Biology ${ }^{4}$, University of Manitoba, and the James Hogg iCapture Centre, McDonald Research Laboratories ${ }^{5}$, University of British Columbia.

\section{INTRODUCTION}

A negative consequence of mechanical ventilation using lower tidal volumes $\left(\mathrm{V}_{\mathrm{T}}\right)$ in patients with the acute respiratory distress syndrome (ARDS) is alveolar collapse. Recruitment manoeuvres (RMsthe application of high levels of positive airway pressure for short periods of time) have been proposed to inflate these atelectatic areas of lung.

In the present study, we compared biologically variable ventilation (BVV) with conventional control mode ventilation (CMV), and to CMV with $\mathrm{RMs}-40 \mathrm{~cm} \mathrm{H}_{2} \mathrm{O}$ positive pressure for $40 \mathrm{sec}$ (CMV$\mathrm{RM}$ ) hourly for $5 \mathrm{hrs}$. BVV is a unique version of CMV that uses a computer-controller to return physiological variability or "noise" to mechanical ventilators. By varying the frequency and $\mathrm{V}_{\mathrm{T}}$ of delivered breaths (via changes in peak airway pressure), BVV may provide an alternative means to recruit atelectatic areas seen with ARDS.

\section{METHODS}

After obtaining approval from the University of Manitoba animal care committee, pigs received mechanical ventilation $\left(\mathrm{F}_{\mathrm{I}} \mathrm{O}_{2}=0.3\right.$; PEEP $\left.5 \mathrm{~cm} \mathrm{H} \mathrm{H}_{2} \mathrm{O}\right)$ with $\mathrm{CMV}$ until $\mathrm{PaO}_{2}$ decreased to $60 \mathrm{mmHg}$ with oleic acid infusion $\left(\mathrm{PaO}_{2} / \mathrm{F}_{\mathrm{I}} \mathrm{O}_{2}<200 \mathrm{mmHg}\right)$. Additional PEEP to $10 \mathrm{~cm} \mathrm{H}_{2} \mathrm{O}$ was added after injury. Animals were randomized to one of the 3 modes of ventilation and followed for $5 \mathrm{hr}$ after injury. We compared gas exchange, respiratory mechanics, and measured bronchoalveolar fluid for inflammatory cytokines, cell counts and surfactant function. Lung injury was scored by light microscopy.

\section{RESULTS}

$\mathrm{PaO}_{2}$ (Figure) and respiratory system compliance were significantly greater with BVV compared to the other two groups. Mean and mean peak airway pressures were lower with BVV. There were no differences in cell counts in bronchoalveolar fluid by flow cytometry, or cytokine levels between groups. Lung injury scores revealed no difference between groups in the regions examined. No differences in surfactant function were seen by capillary surfactometry.

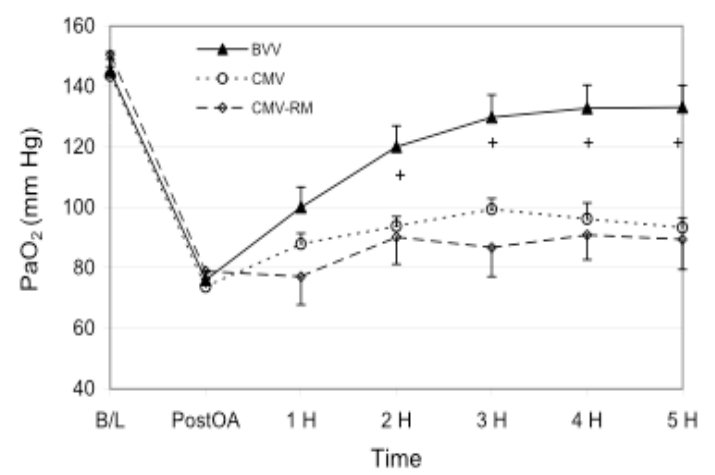

\section{DISCUSSION}

Our study shows that BVV improves gas exchange and respiratory mechanics in a porcine model of ARDS when compared with CMV and CMV-RM. This improvement occurs with lower peak and mean airway pressure. There was no difference between groups in indices of lung injury, inflammation or surfactant function. This study suggests that BVV has the potential to be superior to conventional ventilatory management of ARDS because oxygenation is improved without evidence of increased risk for volutrauma. 